\title{
Evaluation of bacteriophages in the biocontrol of Pseudomonas syringae pv. syringae isolated from cankers on sweet cherry (Prunus avium L.) in Turkey
}

\author{
Mustafa Akbaba ${ }^{1 *}$ (D) and Hatice Ozaktan² (D)
}

\begin{abstract}
Background: Bacterial canker and subsequent gummosis are caused by multiple pathogens and lead to significant yield and productivity losses in sweet cherry cultivation in Turkey. This study identified that Pseudomonas syringae pathovars were responsible for bacterial canker on sweet cherry orchards by using classical and molecular methods and evaluated the biocontrol effects of bacteriophages against $P$. syringae pv. syringae.

Results: Pathogenic bacteria were isolated from samples taken from plants showing symptoms of bacterial canker in cherry orchards located in Izmir and Manisa provinces. Specific pathogens were identified using pathogenicity, phenotypic tests, and simplex PCR. Bacteriophages effective against $P$. syringae strains were isolated from soil contaminated with pathogens identified in the diseased orchards using an optimized isolation protocol. The biocontrol activity of bacteriophage isolates against $P$. syringae pv. syringae was tested in vitro and in vivo. The results of pathogenicity tests on immature sweet cherry fruits and micropropagated cherry plantlets revealed 10 pathogenic bacteria isolates from 44 plant samples taken from sweet cherry orchards showing symptoms of bacterial canker.

Conclusions: Ten isolates were identified as Pseudomonas syringae pv. syringae. Nine different pure bacteriophage isolates were effective. The results indicated that bacteriophage isolates may demonstrate variable reactivity against P. syringae pathovars.
\end{abstract}

Keywords: Sweet cherry, Bacterial canker, Bacteriophage, Micropropagation, Plant-associated bacteria

\section{Background}

The sweet cherry (Prunus avium L.) is believed to have originated in the region that includes the Caspian and Black Sea coasts and subsequently introduced to Europe by birds (Iezzoni et al. 2017). Turkey is the leading global producer of cherries (599,650 tons/year), but they are also propagated on a large scale by the USA, Iran, Chile, Uzbekistan, Italy, and Spain (Faostat 2016). Bacterial canker and subsequent gummosis (hereafter

\footnotetext{
*Correspondence: mustafa.akbaba@outlook.com

'Department of Plant Protection, Faculty of Agriculture, University of Igdir,

76000 Merkez, Igdir, Turkey

Full list of author information is available at the end of the article
}

referred to as bacterial canker) cause significant economic losses to cherry production and yield in all production regions worldwide. Bacterial canker is the general term for diseases caused by multiple disease agents on stone fruit trees (Otto et al. 2017). The most typical symptoms of disease are canker and necrosis, which usually develop around bud eyes, wounds, and branch joints. Because infection is directly related to climatic conditions and pathogens move systemically from the initially infected plant tissues to neighboring tissues, economic and trade-related losses due to bacterial canker may change dramatically from year to year. 
Economic losses result from a reduction in fruit yield and death of branches or entire trees (Ertimurtas 2012).

The study, carried out by Türkoglu et al. (1977), is the first record in Turkey regarding the isolation of Pss as the cause of cankers on apricot trees. The causal agents may be harbored on hosts other than cherries, cause systemic infections without symptoms, and develop as epiphytes on non-host plants, making control of the disease challenging (Ertimurtas 2012). Cultural precautions, use of resistant varieties, and treatments with beneficial microorganisms as a biocontrol agent, antibiotics, and copper applications are all used to control bacterial canker (Kennelly et al. 2007), although the use of antibiotics against plant diseases has been prohibited in the European Union since 2007. Bacteriophages are bacteriaspecific viruses that infect bacterial cells and use bacterial processes to replicate (Kutter and Sulakvelidze 2004). Bacteriophages have been used effectively as a part of integrated disease management strategies (Buttimer et al. 2017). As it is challenging to definitively diagnose the disease agents that cause bacterial canker in cherry, an integrated approach should be used to identify P. syringae isolates by their phenotypic and genomic heterogeneity.

Ten pathogenic bacterial isolates were cultured from cherry orchard samples showing symptoms. Pathogenicity tests are as necessary as biochemical and molecular tests in the detection and diagnostic of $P$. syringae isolates. According to Kałużna and Sobiczewski (2009), tests on immature cherry fruit provided an effective preassessment in determining the isolate pathogenicity. The use of micropropagated plantlets to perform bacterial inoculation is a fast and straightforward method of determining disease symptoms in cherry plants without wounding the studied plants or exposing the plants to cold (Vicente and Roberts 2003).

The management of many fruit tree diseases caused by $P$. syringae pathovars is very difficult due to the lack of effective chemical or biological control measures, limited host resistance, and the endophytic nature of the pathogen at some stages of the disease cycle (Kennelly et al. 2007). Fruit trees infected with $P$. syringae pathovars are relatively challenging to treat once disease symptoms begin to occur. The use of bacteriophages rather than standard chemical control measures for plant disease control is a rapidly developing biological control method with great potential in plant protection, especially as antibiotic and copper resistance increases. Therefore, the aim of this study was to identify the species and pathovars responsible for bacterial canker, using classical and molecular methods and utilizing selected bacteriophages (isolated from soils where diseased orchards are planted) against the causal agents of bacterial canker.

\section{Methods}

\section{Collection of diseased plant samples}

Surveys were conducted during the spring and autumn of 2014 and 2015 in sweet cherry orchards located at 17 different sites in İzmir and Manisa provinces. Samples symptomatic for bacterial canker were randomly collected from different parts of the infected cherry trees (shoots, trunk, leaf, fruit) found in the orchards where bacterial canker was observed. The diseased plant parts were cut from trees using sterile equipment, placed in polyethylene bags, and stored at $4{ }^{\circ} \mathrm{C}$ until the isolation process.

\section{Isolation and growth conditions of bacteria}

Tissue samples were taken from the leaf, bud, flower, and offshoot showing symptoms of the disease were (surface) sterilized by $70 \%$ ethanol $(1 \mathrm{~min})$ and sterile water $(1 \mathrm{~min})$. The 3 -mm fragment was excised in sterile conditions and then crushed in plastic bags containing 10 - $\mathrm{ml}$ sterile phosphate buffer $(0.1 \mathrm{M}, \mathrm{pH}=7.2)$ and incubated in a shaker for $30 \mathrm{~min}$. A 100- $\mu \mathrm{l}$ aliquot of the well-mixed suspension in plastic bags was inoculated via the spread plate method onto King's B medium (Schaad et al. 2001). Petri dishes were incubated for $24 \mathrm{~h}$ at $24 \pm$ $2{ }^{\circ} \mathrm{C}$. Bacterial colonies that were whitish, round, bright, and vitreous with smooth margins on King's B medium were purified by the streak-plate technique (Cazorla et al. 1998). The 38 purified isolates were stored at $80^{\circ} \mathrm{C}$ for long-term use. The production of fluorescent pigment by the bacterial isolates on King's B medium was assessed under $360 \mathrm{~nm}$ UV light. Gram reactions were examined using $3 \% \mathrm{KOH}$ solution. All the bacterial isolates were subjected to a hypersensitivity test using tobacco (Klement et al. 1990; Schaad et al. 2001).

\section{Pathogenicity test on immature fruitlets}

Following the method of Kałużna and Sobiczewski (2009), reference strains and all bacterial isolates were subjected to pathogenicity testing in immature cherry fruitlets (PTIF), Cv. "Napoleon" Sweet cherry fruits were allowed to dry after surface sterilization with $70 \%$ ethanol $(1 \mathrm{~min})$ and sterile water $(1 \mathrm{~min})$. Cultures of the bacterial isolates cultivated on King's B medium for $24 \mathrm{~h}$ at $24 \pm 2{ }^{\circ} \mathrm{C}$ were suspended in sterile water and prepared at a concentration of $10^{9} \mathrm{cfu} / \mathrm{ml}\left(\mathrm{OD}_{600}, 0.1\right)$. A $10-\mu l$ droplet of bacterial suspension was pipetted onto each of the marked areas at two inoculation points opened with sterile needles on the disinfected immature sweet cherry fruits. As a positive control, immature sweet cherry fruits were inoculated by Pss strain BAY3, Psm R1 strain 25B, and Psm R2 strain 732 obtained from Poland. The negative control was treated only by sterile distilled water. The treated fruits were incubated in sterile glass Petri dishes $(9 \mathrm{~mm})$, on double-layer, moistened 
sterile blotting paper at $24^{\circ} \mathrm{C}$ and high relative humidity for up to 6 days. At the end of the incubation period, the inoculation points were evaluated as "present" if symptoms were observed or "absent."

\section{Phenotypic characteristics of bacterial isolates}

The pathogenic isolates were further characterized using common phenotypic tests for $P$. syringae. LOPAT tests (levan production $[\mathrm{L}]$, oxidase activity $[\mathrm{O}]$, pectinolytic activity $[\mathrm{P}]$, arginine dihydrolase $[\mathrm{A}]$, hypersensitivity to tobacco [T]) were used for each bacterial isolates (Klement et al. 1990; Schaad et al. 2001). Methods commonly used for pathovar discrimination of $P$. syringae strains are GATTa (gelatine hydrolysis [G], aesculin hydrolysis $[\mathrm{A}]$, tyrosinase activity $[\mathrm{T}]$, tartrate utilization [Ta]) and L-lactate tests (Janse 2010). The P. syringae pv. tomato (Pst) strain DO24, Pss strain BAY3 (from our lab collection), Psm R1 (race-1) strain 25B, and Psm R2 (race-2) strain 732 were used as reference strains. Data published by Janse (2010) (GATTa; Pss [++--], Psm R1[--++], Psm R2 [++--]) were used as diagnostic keys.

\section{Molecular diagnosis of pathogenic bacteria isolates}

PCR was used to determine the pathovar and race of $P$. syringae strains isolated from diseased cherry trees. The protocols were generally based on the detection of pathogen toxin coding genes. Molecular diagnosis using PCR was conducted using primer sets (Table 1) and designed for the syrB encoding syringomycin production, the cfl encoding coronatine toxin production, and the irp1 encoding yersiniabactin siderophore production (Janse 2010). The results were evaluated using Janse (2010) as a reference for the discrimination of Pss (syrB [+/few -], cfl [-], irp1 [-]), Psm R1 (syrB [-], cfl [+/few -], irp1 [-]), and Psm R2 (syrB [-], cfl [-], irp1 [+]).

DNA was extracted from pure culture by the boiling method. All primers were obtained from Medsantek (Turkey). DNA for discrimination of pathovars of $P$. syringae was amplified using three different $\mathrm{PCR}$ primer sets: cfl primers (Bereswill et al. 1994), syrB primers (Sorensen et al. 1998), and the irp1 primers (Bultreys et al. 2006). The final reaction mixture for each primer sets was prepared as suggested in the literature (Table 1). Amplification of the bacterial genes was conducted in a thermal cycler (Eppendorf ${ }^{\oplus}$ Mastercycler Personal). The thermal cycling profiles for all primer sets were used (Table 1). PCR products were prepared by $0.5 \times$ TAE buffer $(50 \times$ Tris-acetate-EDTA, Fermentas $)$, stained with RedSafeT nucleic acid staining solution (20.000x) (iNtRON Biotechnology), and run on a $1.5 \%$ agarose gel at $80 \mathrm{~V}$ for $90 \mathrm{~min}$. DNA bands were visualized under UV light using GeneRuler ${ }^{\mathrm{Tm}} 100 \mathrm{bp}$ and $1 \mathrm{~kb}$ DNA Ladder (Fermentas).

\section{Pathogenicity of Pseudomonas syringae isolates on micropropagated plantlets}

For the pathogenicity test, micropropagated cherry plantlets of clone rootstock Ma $\times$ Ma 14 (P. mahaleb $\times$ $P$. avium) (Agromillora, İzmir) were used. Pathogenicity was assessed with isolates that were preliminarily identified as $P$. syringae. Bacterial cultures were grown in King's B medium at $24 \pm 2{ }^{\circ} \mathrm{C}$ for $24 \mathrm{~h}$, a loopful was used to prepare a suspension in pure, sterile water at a concentration of $\left(10^{9} \mathrm{cfu} / \mathrm{ml}, \mathrm{OD}_{600}: 0.1\right)$, and 1-2 drops of Tween were added to the suspension. For the inoculation method, a spraying technique was preferred for applying the bacterial isolates to leaves to prevent the creation of wounds on the plants and for ease of application. Micropropagation plantlets (5-6 leaf cherry plants) were replanted into pots $10 \mathrm{~cm}$ in diameter containing sterile peat. Approximately $10 \mathrm{ml}$ of the bacterial suspension was sprayed per plantlet in a way that covered the abaxial side of the plant leaves. Pure and sterile water-treated plantlets were evaluated as the negative control, and reference $P$. syringae strains inoculated plantlets as the positive control. After bacterial

Table 1 Primers, amplicon sizes, and references used in the study

\begin{tabular}{|c|c|c|c|c|c|}
\hline $\begin{array}{l}\text { Target } \\
\text { gene }\end{array}$ & $\begin{array}{l}\text { Primer } \\
\text { names }\end{array}$ & $\begin{array}{l}\text { Oligonucleotide } \\
\text { sequence }\end{array}$ & Cycle conditions & $\begin{array}{l}\text { Amp. } \\
\text { size }\end{array}$ & References \\
\hline \multirow[t]{2}{*}{ irp1 } & PSYE2 & $\begin{array}{l}\text { 5'-GGCACCTGGA } \\
\text { ACAGG-3' }\end{array}$ & \multirow{2}{*}{$\begin{array}{l}\text { The program was as follows: an initial denaturation at } 94^{\circ} \mathrm{C} \text { for } 5 \text { min; } 37 \text { cycles at } \\
94^{\circ} \mathrm{C} \text { for } 1 \mathrm{~min}, 64^{\circ} \mathrm{C} \text { for } 1 \mathrm{~min} \text {, and } 72^{\circ} \mathrm{C} \text { for } 1 \mathrm{~min} \text {; and a final elongation at } 72^{\circ} \mathrm{C} \\
\text { for } 6 \text { min }\end{array}$} & \multirow[t]{2}{*}{$\begin{array}{l}943 \\
b p\end{array}$} & \multirow[t]{2}{*}{$\begin{array}{l}\text { Bultreys } \\
\text { et al. (2006) }\end{array}$} \\
\hline & PSYE2R & $\begin{array}{l}\text { 5'-GCCAGATCGT } \\
\text { CCATCAT-3' }\end{array}$ & & & \\
\hline \multirow[t]{2}{*}{ syrB } & $\begin{array}{l}\text { Primer } \\
\text { B1 }\end{array}$ & $\begin{array}{l}\text { 5'-CTTTCCGTGG } \\
\text { TCTTGATGAGC-3' }\end{array}$ & \multirow{2}{*}{$\begin{array}{l}\text { The program was as follows: an initial denaturation at } 94^{\circ} \mathrm{C} \text { for } 5 \text { min; } 35 \text { cycles at } \\
94^{\circ} \mathrm{C} \text { for } 1.5 \mathrm{~min}, 60^{\circ} \mathrm{C} \text { for } 1.5 \mathrm{~min} \text {, and } 72^{\circ} \mathrm{C} \text { for } 3 \text { min; and a final elongation at } 72^{\circ} \mathrm{C} \\
\text { for } 10 \text { min }\end{array}$} & \multirow{2}{*}{$\begin{array}{l}752 \\
b p\end{array}$} & \multirow[t]{2}{*}{$\begin{array}{l}\text { Sorensen } \\
\text { et al. (1998) }\end{array}$} \\
\hline & $\begin{array}{l}\text { Primer } \\
\text { B2 }\end{array}$ & $\begin{array}{l}\text { 5'-TCGATTTGC } \\
\text { CGTGATGAGTC-3' }\end{array}$ & & & \\
\hline \multirow[t]{2}{*}{$\mathrm{cfl}$} & Primer1 & $\begin{array}{l}\text { 5'-GGCGCTCCCT } \\
\text { CGCACTT-3' }\end{array}$ & \multirow{2}{*}{$\begin{array}{l}\text { The program was as follows: an initial denaturation at } 93^{\circ} \mathrm{C} \text { for } 2 \text { min; } 37 \text { cycles at } \\
93^{\circ} \mathrm{C} \text { for } 1 \mathrm{~min}, 67^{\circ} \mathrm{C} \text { for } 1 \mathrm{~min} \text {, and } 72^{\circ} \mathrm{C} \text { for } 2 \mathrm{~min} \text {; and a final elongation at } 72^{\circ} \mathrm{C} \\
\text { for } 10 \mathrm{~min}\end{array}$} & \multirow[t]{2}{*}{$\begin{array}{l}650 \\
b p\end{array}$} & \multirow[t]{2}{*}{$\begin{array}{l}\text { Bereswill } \\
\text { et al. (1994) }\end{array}$} \\
\hline & Primer2 & $\begin{array}{l}5^{\prime}-\text { GGTATTGG } \\
\text { CGGGGGTGC-3' }\end{array}$ & & & \\
\hline
\end{tabular}


inoculation, the plantlets were stored in polyethylene bags to ensure high humidity, exposed to a 16-h photoperiod at $22 \pm 2{ }^{\circ} \mathrm{C}$ for $48 \mathrm{~h}$, and then the bags were opened. Trials were conducted in plant growth chamber conditions with four replicates and with one plantlet per replicate. Trials followed a completely randomized design and repeated twice. Symptoms were evaluated 10 days after pathogen inoculation using the $0-9$ scale: 0 , no symptoms; 1 , the presence of small necrotic or chlorotic areas on one leaf of the plant; 3 , the presence of necrotic or chlorotic lesions on less than half the plant; 5 , the presence of necrotic or chlorotic lesions on half of a plant; 7 , the presence of necrotic lesions on more than half of a plant, on the stem and the leaves; and 9, dead plant (Vicente and Roberts 2003). The percent disease index was calculated.

\section{Collection of soil samples for bacteriophage isolation} In 2014 and 2015, soil samples (approximately 30-cmdeep) for isolation of bacteriophages specific for P. syringae pathovars were collected from sweet cherry orchards with symptoms of bacterial canker in 17 different locations in İzmir and Manisa provinces. Soil samples containing a small amount of plant debris were collected during spring and autumn seasons from crown projections of cherry trees showing intense bacterial canker symptoms, the samples were then placed in polyethylene bags and stored at $4{ }^{\circ} \mathrm{C}$ until bacteriophage isolation.

\section{Bacteriophage isolation, purification, and preservation}

Isolation of active bacteriophages against $P$. syringae pv. syringae was conducted by protocols described in previous studies with appropriate modifications (Crosse and Hingorani 1958; Gašić et al. 2011; Cross et al. 2015). The bacteriophage isolation procedure consisted of the following steps: enrichment, isolation, purification, and preservation.

\section{Enrichment}

Liquid enrichment medium $(50 \mathrm{ml})$ was prepared to contain $50 \mathrm{~g} / \mathrm{l} \mathrm{CaCO} 3$ and $8 \mathrm{~g} / \mathrm{l}$ nutrient broth in $250-\mathrm{ml}$ conical flasks and sterilized. The cultures of the bacterial isolates developed on the King's B medium for $24 \mathrm{~h}$ at $24 \pm 2{ }^{\circ} \mathrm{C}$ were suspended in sterile distilled water. Flasks were inoculated with $5-\mathrm{ml}$ water suspension with a concentration of $10^{9} \mathrm{cfu} / \mathrm{ml}\left(\mathrm{OD}_{600}: 0.1\right)$ of the target bacterial isolate. The flasks were then thoroughly mixed for 1-2 min, and $50 \mathrm{~g}$ of sieved moist soil sample was added. The mixture was incubated in the shaker at $160 \mathrm{rpm}$ at $24 \pm 2{ }^{\circ} \mathrm{C}$ for $24 \mathrm{~h}$.

\section{Isolation}

Two different mixtures (each $1 \mathrm{ml}$ ) were removed from the soil samples incubated in the shaker at $160 \mathrm{rpm}$ at
$24 \pm 2{ }^{\circ} \mathrm{C}$ for $24 \mathrm{~h}$. These mixtures were centrifuged in $1.5-\mathrm{ml}$ Eppendorf tubes at $14,000 \mathrm{~g}$ for $6 \mathrm{~min}$. After centrifugation, approximately $500 \mu \mathrm{l}$ of the supernatant from each tube was transferred to a new Eppendorf tube. A total of $1000 \mu \mathrm{l}$ of the supernatant collected from both tubes was mixed, chloroform $(10 \%, \mathrm{v} / \mathrm{v})$ was added, the supernatant was incubated for $20 \mathrm{~min}$, and $500 \mu \mathrm{l}$ was transferred to a new tube and stored at $4{ }^{\circ} \mathrm{C}$ for subsequent steps. Spot inoculation and the double agar method were used to observe the formation of phage plaques (Gašić et al. 2011). In both methods, $\mathrm{CaCl}_{2}(1.5$ $\mathrm{g} / \mathrm{l})$ was added to the medium to enhance the attachment of phages to the host cell surface. The dilution series in the study was prepared within the phage buffer ( $4 \mathrm{~g} \mathrm{NaCl}, 1.2 \mathrm{~g} \mathrm{MgSO}_{4}, 1.2 \mathrm{~g}$ Tris- $\mathrm{Cl}$, and $1 \mathrm{~L} \mathrm{H}_{2} \mathrm{O}$ ).

\section{Purification}

The phage plaques that appeared to be well-formed were picked from the agar using a sterile toothpick. The toothpick was then, immersed into the Eppendorf tube containing $100 \mu \mathrm{l}$ of phage buffer, stirred in the buffer, and vortexed slowly. A dilution series was prepared from the phage suspension. After dilution, the double agar and spot inoculation methods were applied. Then, the phage plaques and inhibition zones that appeared by phages were controlled. This phase was repeated three times to ensure the phage isolate was pure.

\section{Preservation}

After the final purification phase, phages with wellformed plaques on the double agar medium were allowed to incubate. After plaque formation, 5-ml of phage buffer was added to the Petri dishes. Then, the top agar on the surface was crushed thoroughly. The phage suspension with agar was gently vortexed in Falcon tubes. After centrifugation, approximately $1 \mathrm{ml}$ of supernatant was taken from each tube and slowly filtered through a $0.22-\mu \mathrm{m}$ filter. The acquired supernatant was treated with $10 \%(\mathrm{v} / \mathrm{v})$ of chloroform for $20 \mathrm{~min}$. Phages of this final supernatant were stored in the storage medium (NB $+30 \%$ glycerol) as triplicates at $-80^{\circ} \mathrm{C}$. The presence of phage was observed using double-layer agar and spot inoculation methods. Finally, the phage stock was re-tested for vitality control within a few days using the double-layer agar method. After incubation in the medium for $24-48 \mathrm{~h}$, the phage concentration of the $-80^{\circ} \mathrm{C}$ stock was estimated by the bacterial counting formula of Klement et al. (1990) and was considered as plaque-forming units per $\mathrm{ml}(\mathrm{pfu} / \mathrm{ml})$. Finally, the density that could lyse the bacteria was determined by the spot inoculation method. 
In vitro biocontrol activity of bacteriophages against $P$. syringae pathovars

The spot inoculation method was used to check the biocontrol activity of bacteriophages against $P$. syringae pathovars. Briefly, cultures of the bacterial isolates grown on the King's B medium at $24 \pm 2{ }^{\circ} \mathrm{C}$ for $24 \mathrm{~h}$ were prepared at a concentration of $10^{9} \mathrm{cfu} / \mathrm{ml}\left(\mathrm{OD}_{600}: 0.1\right)$ in sterile water, then $100 \mu \mathrm{l}$ of the bacterial suspension was placed onto the center of a sterile Petri dish. Top agar was poured over it, then spread and mixed with the suspension. After medium solidification, $10 \mu \mathrm{l}$ of the tested bacteriophage suspension was used to spot inoculate the medium surface. According to the inhibition zones appearing after $24-48 \mathrm{~h}$, the results were evaluated as "with effect" or "without any effect."

\section{In vivo biocontrol activity of bacteriophages against $P$. syringae pathovars}

The effects of bacteriophage isolates against Pss were determined on micropropagated cherry plantlets in vivo. Phages were revived by dilution and the double-layer agar overlay procedure from phages stocks at $-80^{\circ} \mathrm{C}$. Phage suspensions added to the medium containing 100 $\mathrm{ml}$ of NB-CaCl 2 were incubated on a rotary shaker (160 $\mathrm{rpm})$ for $18-24 \mathrm{~h}$ at $24 \pm 2{ }^{\circ} \mathrm{C}$. They were then centrifuged at $8000 \mathrm{~g}$ for $5 \mathrm{~min}$, and 2 drops of Tween 80 were added to the resulting phage supernatants. Twelve hours post-inoculation of the pathogen, phage supernatants were sprayed onto micropropagation plantlets at $10 \mathrm{ml}$ per plantlet. Phages were applied to the plantlets individually and in combination (5 phage isolates) (Boulé et al. 2011). Positive control plantlets were treated with $\mathrm{NB}-\mathrm{CaCl}_{2}$, which was incubated on a rotary shaker for 18-24 $\mathrm{h}$ and also Pss suspension. Negative control plantlets were treated with $\mathrm{NB}-\mathrm{CaCl}_{2}$ and incubated on a rotary shaker for $18-24 \mathrm{~h}$, and sterile water. Twelve hours before the phage treatment, approximately $10-\mathrm{ml}$ pathogenic bacteria was sprayed onto each micropropagation cherry plantlet. Treated plantlets were kept in the darkness for $12 \mathrm{~h}$ to increase the bacteriophages' chance to adapt and survive against UV radiation. The treated plantlets were kept in polyethylene bags to ensure high humidity (approximately $96 \%$ ) in a 16 -h photoperiod at $22 \pm 2{ }^{\circ} \mathrm{C}$ for $48 \mathrm{~h}$, and then, the bags were opened. Simultaneously, the phage density in each phage supernatant treatment $(1 \mathrm{ml})$ was calculated by the double-layer agar. Trials were conducted in plant growth chamber conditions with four replicates and with one plantlet (5-6 leaf plant) per replicate. Trials were designed according to a completely randomized and repeated twice. Symptoms were evaluated, 10 days after pathogen inoculation using the 0-9 scale, and disease severity values were obtained (Vicente and Roberts 2003). The percentage disease index was calculated.

\section{Statistical analysis}

All data were analyzed using Microsoft Excel 2010 and SPSS (IBM SPSS Statistics, version 18.0). Variance analysis (ANOVA) was applied, and the differences among the averages were determined by Duncan's multiple comparison test. The percent of the disease index was calculated using the formula DI $=(\Sigma$ [Number of plants in the rating $\times$ Rating number]/[total number of plants $\times$ the highest rating]) $\times 100 \%$ (Liu et al. (1995)).

\section{Results}

\section{Establishment of a bacterial collection}

Thirty-eight bacterial isolates were isolated from 44 plant samples showing disease symptoms. Bacterial colonies could not be isolated due to excessive fungal growth in 6 out of 44 diseased plant samples. From the rest of the samples, 38 candidate bacteria potentially pathogenic on sweet cherry were isolated with characteristic colony morphology. However, most of the bacterial isolates were determined not to be the causal agents of bacterial canker by the results of the pathogenicity and other tests. These bacterial isolates were considered to be non-pathogenic or saprophytic species that survived due to symptoms/disorders caused by other pathogens and abiotic factors. Among the 38 isolates, 10 isolates were selected as they met the following criteria: Gram $(-)$, HR in tobacco $(+)$, and pathogenicity test in immature cherry fruit $(+)$. These isolates were identified as BY3L238, A2L245, Ö3L2308, A3F1310, K2L312, Ö3L1315, BY5L316, AL1T3324, AL1T1343, and HAL3T348.

\section{Phenotypic characteristics of bacterial isolates}

Ten isolates among the 38 isolates were determined to be pathogenic according to the results of the pathogenicity test on immature fruits. Then, they were subjected to LOPAT and GATTa tests. According to these test results, 10 isolates matched with reference Pss strain BAY3 isolate, and they were different from other reference strains (Table 2).

\section{Molecular detection of bacterial isolates}

According to the primer set designed for the syrB gene used by Sorensen et al. (1998) and the PCR results, 10 isolates together with Pss strain BAY3 as a reference showed the presence of a 752-bp fragment (references: Psm R1 strain 25B [-], Psm R2 strain 732 [-]). According to the primer set designed for the $\mathrm{cfl}$ used by (Bereswill et al. 1994) and the PCR results, P. syringae pv. tomato $[P s t]$ strain DO24, which is used for positive control purposes and known to produce the coronatin toxin, showed the amplification of a 650-bp fragment. Ten isolates and the reference strains Pss BAY3, Psm R1 strain 25B, and Psm R2 strain 732 did not show the presence 
Table 2 Pathogenicity results on immature fruits (PTIF), LOPAT, GATTa, and PCR (syrB, cfl, irp1) results of bacterial isolates

\begin{tabular}{|c|c|c|c|c|c|c|c|c|c|c|c|c|c|c|c|c|}
\hline \multirow{2}{*}{$\begin{array}{l}\text { Isolate } \\
\text { code }\end{array}$} & \multicolumn{13}{|c|}{ Phenotypic tests } & \multicolumn{3}{|l|}{ PCR } \\
\hline & PTIF & $\mathrm{Gr}$ & $\mathrm{Fp}$ & Le & Ox & $\mathrm{Pe}$ & $\mathrm{Ar}$ & $\mathbf{T}$ & $\mathrm{Ge}$ & $\mathrm{Ae}$ & Ty & $\mathrm{Ta}$ & La & syrB & $\mathrm{cfl}^{*}$ & irp1 \\
\hline PSS BAY3 & + & - & + & + & - & - & - & + & + & + & - & - & + & + & - & - \\
\hline Psm 25B & + & - & + & + & - & - & - & + & - & - & + & + & - & - & - & - \\
\hline Psm 732 & + & - & + & + & - & - & - & + & + & - & - & - & - & - & - & + \\
\hline BY3L238 & + & - & + & + & - & - & - & + & + & + & - & - & + & + & - & - \\
\hline A2L245 & + & - & + & + & - & - & - & + & + & + & - & - & + & + & - & - \\
\hline Ö3L2308 & + & - & + & + & - & - & - & + & + & + & - & - & + & + & - & - \\
\hline A3F1310 & + & - & + & + & - & - & - & + & + & + & - & - & + & + & - & - \\
\hline K2L312 & + & - & + & + & - & - & - & + & + & + & - & - & + & + & - & - \\
\hline Ö3L1315 & + & - & + & + & - & - & - & + & + & + & - & - & + & + & - & - \\
\hline BY5L316 & + & - & + & + & - & - & - & + & + & + & - & - & + & + & - & - \\
\hline AL1T3324 & + & - & + & + & - & - & - & + & + & + & - & - & + & + & - & - \\
\hline AL1T1343 & + & - & + & + & - & - & - & + & + & + & - & - & + & + & - & - \\
\hline HAL3T348 & + & - & + & + & - & - & - & + & + & + & - & - & + & + & - & - \\
\hline
\end{tabular}

of a 650-bp fragment. According to the primer set designed for the irp1 used by Bultreys et al. (2006) and PCR results, Psm R2 strain 732 as a reference of race-2 was the only isolate that showed amplification of a 943bp fragment (Table 2), and that was the only fragment of interest found in that isolate. Ten of the isolates from the study (BY3L238, A2L245, Ö3L2308, A3F1310, K2L312, Ö3L1315, BY5L316, AL1T3324, AL1T1343, HAL3T348) were verified as Pss according to the PCR results for 3 different genes, phenotypic characteristics, pathogenicity, and molecular diagnostics.

\section{Pathogenicity of Pseudomonas syringae isolates on micropropagated plantlets}

The average results of two trials of pathogenicity assays performed on $10 \mathrm{P}$. syringae isolates and 3 reference strains (Pss/Psm R1/Psm R2) are presented (Table 3). The average disease index was $37.1 \%$ in the positive control plantlets inoculated with reference Pss strain BAY3, and a higher disease index was reported in Ö3L2308, BY5L316, the coded Pss isolates, and the reference Psm R2 strain 732 isolate compared to the positive control. In cherry plantlets, the pathogenicity of Pss isolate BY5L316 was found to be statistically significant, with a 46.5\% disease index rate compared to the reference Pss strain BAY3 and all other isolates.

Isolation, purification, and preservation of bacteriophages Soil samples were taken from 17 different locations in İzmir and Manisa provinces in 2014, but no bacteriophage could be isolated due to the unsuitable sampling time (the initial incidence of the bacterial infection). In
2015, the collection of 36 different soil samples allowed for successful isolation of nine different pure phage isolates (Ф911, Ф922, Ф943, Ф954, Ф1215, Ф1226, Ф137, Ф358, and Ф369) from soil samples collected from four locations (Ören, Bağyurdu, Yukarıcobanisa, and Aşağıcobanisa). Bacteriophage isolates purified during the last

Table 3 Pathogenicity results of Pseudomonas syringae isolates on micropropagated cherry plantlets within a growth chamber

\begin{tabular}{ll}
\hline Average of experiments I-II & \\
\hline Isolate code & Average disease index (\%)* \\
\hline K2L312 & $16.7 \pm 0.86 \mathrm{a}^{* *}$ \\
BY3L238 & $18.5 \pm 0.51 \mathrm{a}-\mathrm{c}$ \\
HAL3T348 & $20.4 \pm 0.93 \mathrm{a}-\mathrm{b}$ \\
AL1T1343 & $25.9 \pm 0.51 \mathrm{a}-\mathrm{d}$ \\
A2L245 & $29.6 \pm 0.40 \mathrm{a}-\mathrm{d}$ \\
Ö3L1315 & $29.6 \pm 0.40 \mathrm{a}-\mathrm{d}$ \\
A3F1310 & $29.6 \pm 0.65 \mathrm{a}-\mathrm{d}$ \\
PSS BAY3 & $37.0 \pm 0.61 \mathrm{~b}-\mathrm{d}$ \\
AL1T3324 & $37.0 \pm 0.61 \mathrm{~b}-\mathrm{d}$ \\
PSm 25B & $37.0 \pm 0.82 \mathrm{~b}-\mathrm{d}$ \\
Ö3L2308 & $40.7 \pm 0.35 \mathrm{~cd}$ \\
PSm 732 & $40.7 \pm 0.75 \mathrm{~b}-\mathrm{d}$ \\
BY5L316*** & $46.5 \pm 0.43 \mathrm{~d}$
\end{tabular}

*The results are an average of the two trials. Four plantlets were evaluated in each trial for each treatment

**According to Duncan's multiple comparison test, the difference between the averages indicated by the same letters in the same column is insignificant according to $P<0.05$

***The most virulent isolate, BY5L316, was selected to use in the next stage of the study 
stage were aliquoted into cryoprotectant tubes containing glycerol and NB liquid medium for long-term preservation and stored at $-80{ }^{\circ} \mathrm{C}$. The phage density (pfu/ $\mathrm{ml}$ ) in these tubes was calculated according to Klement et al. (1990) (Table 4). For control purposes, the phages were proven to be present in the tubes by reviving studies from the stock after $48 \mathrm{~h}$. Five different phage isolates (Ф1215, Ф1226, Ф137, Ф358, Ф369) with high lytic activity against Pss were selected for future studies.

\section{In vitro biocontrol activity of bacteriophages against $P$. syringae pathovars}

Bacteriophages against different bacterial isolates showed a range of biocontrol activities (Fig. 1a, Table 5). Pss BAY3 was lysed highly by all phage isolates (Fig. 1b). Psm R1 strain 25B was lysed very effectively by phage isolates $\Phi 1215$ and $\Phi 137$ (Fig. 1c). Psm R2 strain 732 was lysed very effectively by only phage isolate $\Phi 369$ (Fig. 1d). In contrast to the other Pss isolates, the Pss HAL3T348 isolate was unaffected by the other phage isolates except for $\Phi 358$ and $Ф 369$.

\section{In vivo biocontrol activity of bacteriophages against $P$. syringae pathovars}

In trials conducted on micropropagated cherry plantlets in the growth chamber, five bacteriophage isolates and their combinations were used to determine the biocontrol activities against the high-virulence Pss strain BY5L316. The density of bacteriophages in the treatments was reported in Table 6. Average results of two separate trials demonstrated that at 10 days postinoculation, 4 out of 6 phage treatments of the phage treatments (Ф1226, Ф137, Ф358 [Fig. 2a], Ф369) reduced successfully more than $50 \%$ of the disease incidence caused by Pss strain BY5L316 compared to the control (48.1\%, Fig. 2b). Except for $\Phi 1215$ treatment, there was a statistically significant difference between controls and all phage treatments (Table 6).
Combination phage treatment decreased the disease incidence by $42.3 \%$, less than individual phages.

\section{Discussion}

The use of phages for the diagnosis of causal agents of bacterial diseases was introduced in Turkey when it was discovered that bacteriophages could attach to the receptors on the cell wall of bacteria (Erkan and Saygll 1987). This study is one of the first attempts at the use of bacteriophages in the biological control of plant bacterial diseases in Turkey. In recent years, products containing bacteriophages against plant bacterial diseases have been launched commercially by companies based in the USA, Hungary, and Scotland (Buttimer et al. 2017). Bacteriophages with specific effects against Psm NA3 of the causal agents of bacterial canker were isolated first from cherry, plum, and apricot orchards across England (Crosse and Hingorani 1958). The phages were isolated from soil against $P$. syringae pv. syringae which were a causal agent of bacterial canker on sweet cherry in this study. One of the most critical aspects of phage isolation from the soil was sampling time. Payne and Jansen (2001) emphasized that phage treatment must be carefully timed to coincide with a sufficiently dense bacterial population in order to be effective phage therapy. With the emergence of bacterial canker symptoms and the progression of infection, the source of the bacteriophages in the soil was thought to be diseased plant residuals and the products of gummosis, which was likely why bacteriophages have not been isolated from the soil samples collected when the symptoms of bacterial canker firstly appear. Bacteriophages were only found at high titers in soil under conditions suitable for the proliferation of their hosts (Reanney and Marsh 1973). At the phage-host system, it was reported that susceptible host cell populations must reach a critical density before phage replication can occur. In the same study, it has been reported that there was a longer delay before phage numbers increase over the numbers

Table 4 List of bacteriophages isolated from soil

\begin{tabular}{|c|c|c|c|c|c|}
\hline No. & Isolate code & Sample location & $\mathrm{pfu} / \mathrm{ml}$ (- 80 stock) & Plaque sizes ( mm) & Plaque forms on solid media \\
\hline 1 & Ф911 & Ören-6 & $9 \times 10^{7}$ & 1.15 & Smallest and turbid \\
\hline 2 & Ф922 & Ören-6 & $2 \times 10^{6}$ & 0.98 & Smallest and clear \\
\hline 3 & Ф943 & Ören-6 & $5 \times 10^{8}$ & 2.62 & Medium and turbid \\
\hline 4 & Ф954 & Ören-6 & $2 \times 10^{6}$ & 2.48 & Medium and turbid \\
\hline 5 & Ф1215 & Bagyurdu-7 & $3 \times 10^{8}$ & 4.37 & Largest and clear \\
\hline 6 & $\Phi 1226$ & Bagyurdu-7 & $5 \times 10^{8}$ & 4.50 & Largest and clear \\
\hline 7 & Ф137 & Ören-5 & $6 \times 10^{8}$ & 4.22 & Largest and clear \\
\hline 8 & Ф358 & Y. Çobanisa-2 & $2 \times 10^{9}$ & 1.00 & Smallest and clear \\
\hline 9 & Ф369 & A. Çobanisa-3 & $8 \times 10^{9}$ & 0.95 & Smallest and turbid \\
\hline
\end{tabular}

Plaques of different diameter $(\Phi)$ are shown: $\Phi<2 \mathrm{~mm}$ (smallest), $\Phi=2-4 \mathrm{~mm}$ (medium), and $4 \mathrm{~mm}<\Phi$ (largest) 

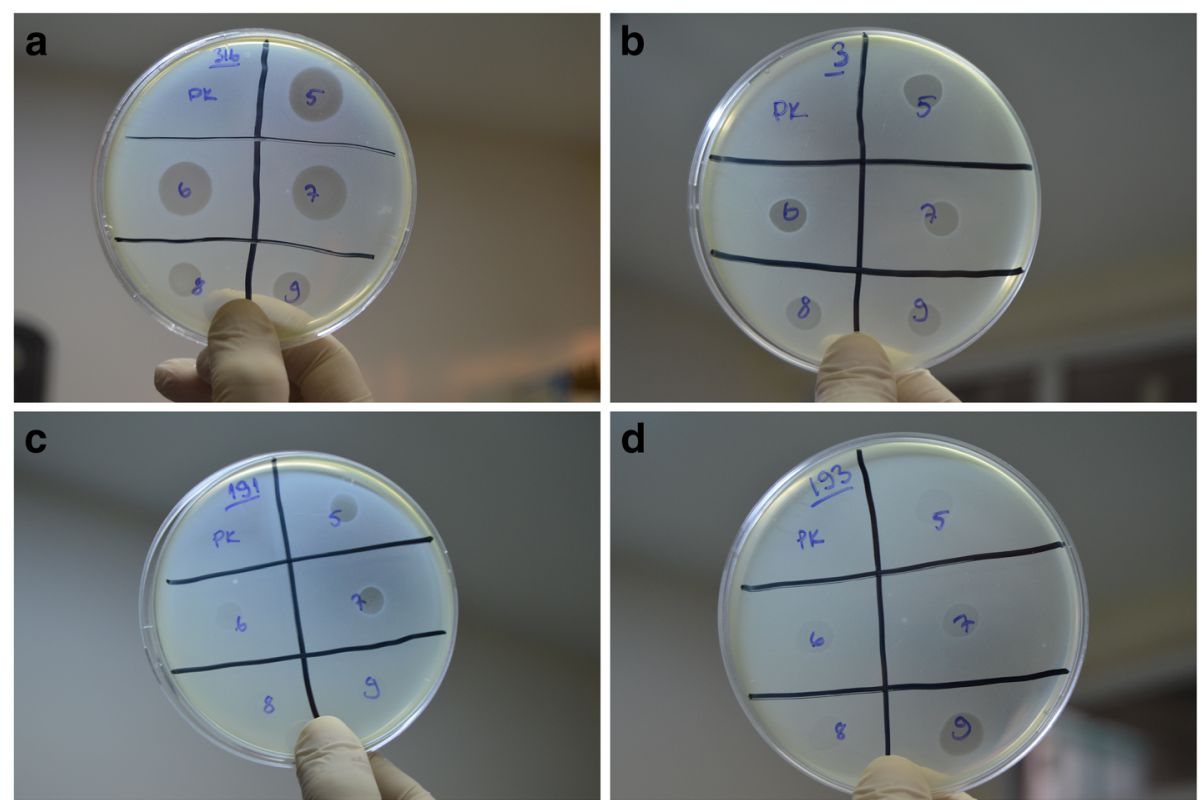

Fig. 1 Lytic effects of bacteriophages (\$1215 [5]; Ф1226 [6]; Ф137 [7]; Ф358 [8]; \$369 [9]) against Pseudomonas syringae pathovars. a Pss strain BY5L316 (the most virulent pathogenic isolate). b Pss strain BAY3 [3]. c Psm R1 strain 25B [191]. d Psm R2 strain 732 [193]). *Numbers in brackets show the location of strains/phages in lab strain/phage collection (e.g., 3 instead of Pss strain BAY3 or 5 instead of (1215)

of input phage when host cell densities were very low (Kasman et al. 2002). Pelzek et al. (2013) reported that $\mathrm{CaCl}_{2}$ improved phage adsorption during the infection process of the host bacteria. It was proposed that to increase the possibility of isolating phages specific to bacteria, the concentrations of $\mathrm{CaCO}_{3}$ in the isolation protocol and $\mathrm{CaCl}_{2}$ in the double-layer method were important, as they affected the success of phage isolation from the soil by allowing the bacteriophages to attach to the bacterial surface. The protocol used for the isolation of phages from soil against causal agents of bacterial canker has been optimized with information collected from different studies and has been used successfully in this study.
The reactions of five phages isolated against three pathogenic Pss agents were detected in vitro. All phages isolated showed substantial lytic effect against Pss. In addition, different reactions to bacteriophages were observed among Pss strains. Bacteriophage isolates $\Phi 1215$, $\Phi 1226$, and $\Phi 137$ showed a lytic effect on all Pss strains except HAL3T348. A widespread belief has emerged, particularly in the field of medicine, that considers the broad-spectrum activity of antibiotics and the narrower spectrum of phages; the failure of phages could be much higher if the pathogen to which the phages will be applied but not identified correctly (Kutter and Sulakvelidze 2004). It was also important because phage isolates that were isolated for one pathovar may have different

Table 5 Host range data between some pathogenic Pseudomonas syringae isolates and bacteriophage isolates

\begin{tabular}{|c|c|c|c|c|c|c|c|c|c|c|c|c|c|}
\hline \multirow[t]{2}{*}{ Phages $^{c}$} & \multicolumn{13}{|c|}{ Pathogen isolates $^{\mathrm{a}}$} \\
\hline & $\begin{array}{l}\text { Pss } \\
\text { BAY3 }\end{array}$ & $\begin{array}{l}\text { Psm } \\
\text { 25B }\end{array}$ & $\begin{array}{l}\text { Psm } \\
732\end{array}$ & $\begin{array}{l}\text { Pss } \\
\text { BY3L238 }\end{array}$ & $\begin{array}{l}\text { Pss } \\
\text { A2L245 }\end{array}$ & $\begin{array}{l}\text { Pss } \\
\text { Ö3L2308 }\end{array}$ & $\begin{array}{l}\text { Pss } \\
\text { A3F1310 }\end{array}$ & $\begin{array}{l}\text { Pss } \\
\text { K2L312 }\end{array}$ & $\begin{array}{l}\text { Pss } \\
\text { Ö3L1315 }\end{array}$ & $\begin{array}{l}\text { Pss } \\
\text { BY5L316 }\end{array}$ & Pss & AL1T3324 & $\begin{array}{l}\text { Pss } \\
\text { AL1T1343 }\end{array}$ \\
\hline Pss & & & & & & & & & & & & & HAL3T348 \\
\hline$\Phi 1215$ & + & + & * & + & + & + & + & + & + & + & + & + & - \\
\hline Ф1226 & + & $*$ & * & + & + & + & + & + & + & + & + & + & - \\
\hline$\Phi 137$ & + & + & * & + & + & + & + & + & + & + & + & + & - \\
\hline Ф358 & + & * & * & + & + & + & + & + & + & + & + & + & + \\
\hline Ф369 & + & * & + & + & + & + & + & + & + & + & + & + & + \\
\hline
\end{tabular}

${ }_{\text {a }}$ seudomonas syringae pv. syringae (Pss), P. syringae pv. morsprunorum [Psm] race 1 (Psm 25B), P. syringae pv. morsprunorum [Psm] race 2 (Psm 732) ${ }^{\mathrm{b}}(+)$ lysis after infection with tested bacteriophage, $(-)$ a lack of lysis after infection with tested bacteriophage, $\left(^{*}\right)$ a weak of lysis after infection with tested bacteriophage

'Undiluted phage stocks in Table 4 were used for this test 
Table 6 Biocontrol (\%) at bacteriophage treatments on Pseudomonas syringae pv. syringae disease's severity in micropropagated cherry plantlets within a growth chamber

\begin{tabular}{|c|c|c|c|}
\hline Treatments & Treatment concentration (pfu/ml) & Average disease index (\%) ${ }^{a}$ & Efficacy $(\%)^{\mathbf{b}}$ \\
\hline Ф1226 & $2,2 \times 10^{9}$ & $9.7 \pm 0.75 \mathbf{a}^{c}$ & 79.8 \\
\hline Ф137 & $1,5 \times 10^{9}$ & $13.9 \pm 0.77 \mathrm{ab}$ & 71.2 \\
\hline Ф358 & $4,1 \times 10^{10}$ & $15.3 \pm 0.63 \mathbf{a b}$ & 68.3 \\
\hline Ф369 & $6 \times 10^{10}$ & $20.8 \pm 1.10 \mathrm{ab}$ & 56.7 \\
\hline ФCombination of phages & $5 \times 10^{9}$ & $27.8 \pm 0.54 \mathbf{b}$ & 42.3 \\
\hline Ф1215 & $4 \times 10^{9}$ & $38.9 \pm 0.49 c$ & 19.2 \\
\hline BY5L316 (control +) & 0 & $48.1 \pm 0.51 c$ & 0.0 \\
\hline
\end{tabular}

a. The results are an average of the two trials. Four plantlets were evaluated in each trial for each treatment

b. Percentage reduction in diseases severity compared to plants treated with pathogen alone

c. Means within columns sharing a letter in common are not significantly different $(P<0.05$; Duncan's test). The standard error of each set is displayed

levels of effectiveness for different pathovars of the same species.

It was also found that $66 \%$ of the phage treatments reduced successfully more than $50 \%$ of the disease incidence caused by Pss strain BY5L316 than the control. In a similar study, bacteriophages have been used alone and in combination with copper bactericides to control the Asiatic citrus canker and citrus bacterial spot caused by Xanthomonas axonopodis pathovars citri and citrumelo, respectively. Although phage treatment was less effective than copper-mancozeb in greenhouse trials, it has significantly reduced the disease severity of citrus canker. Combinations of phage and copper-mancozeb treatments did not show good results compared to copper-mancozeb treatment alone against citrus canker. In the same study, while phage treatment did not reduce the severity of disease of citrus bacterial spot on susceptible grapefruits, it reduced disease severity significantly on the moderately susceptible Valencia oranges in trials. Phage treatment provided a moderate level of control over the citrus bacterial spot in a commercial nursery contaminated with diverse populations of the pathogen (Balogh et al. 2008).

The fact that bacteriophages have effects against multiple disease agents has advantages and disadvantages in terms of biological control of bacterial disease agents. The specificity of bacteriophages to the host and the range of pathogens it affects are critical in combatting bacterial canker caused by multiple bacterial disease agents. In this study, the lytic effect of some isolated bacteriophages against different agents was observed. The phage combinations in different proportions may increase the success of the control against bacterial canker. In terms of biocontrol, the probability of finding a bacterium to be adsorbed by a single phage depended on the time, the density of the phage, the phage diffusion rate, and the local density of the bacteria sensitive to the phage. The more bacteria present will result in faster phage adsorption (Kasman et al. 2002). However, when preparing these combinations, particular attention should be paid to the receptors recognized by a particular phage on a bacterial target. It has been reported that
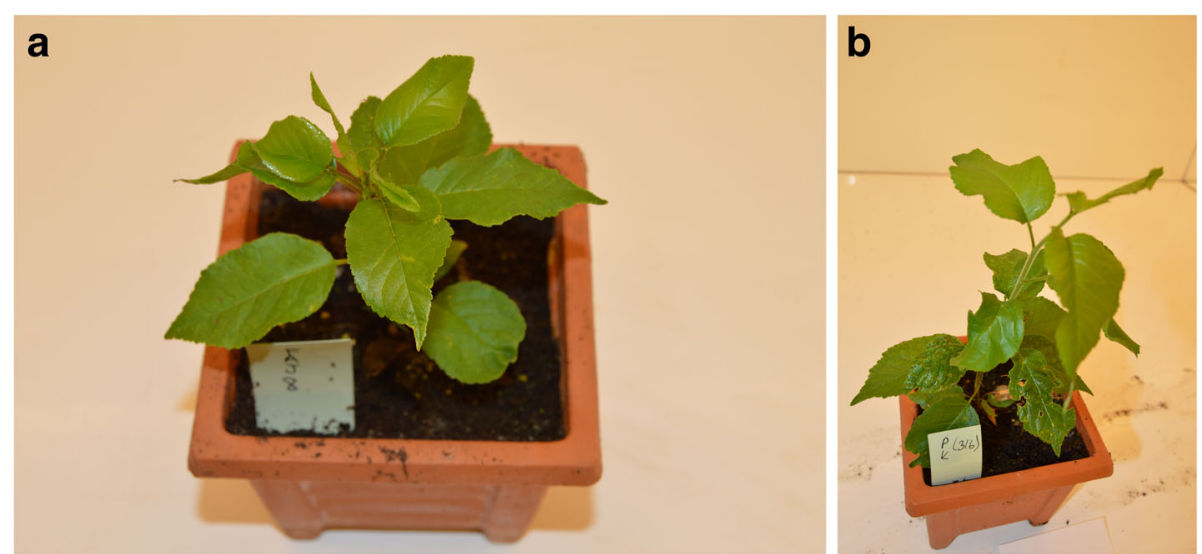

Fig. 2 a Plantlet treated with $\$ 358$ [8] phage treatment on 10 days post-inoculation with Pss strain BY5L316. b Control (+) plantlet treated with only PSS strain BY5L316 on 10 days post-inoculation 
generating phage mixtures may be helpful where the probability of host resistance was low (Frampton et al. 2012) and may lead to the development of phage combinations in which individual members work in synergy to eliminate the target bacteria (Born et al. 2011). In addition to these advantages, the bacteriophages having a wide host range, the possibility of bacteriophage's ineffectiveness, or the possibility of reducing the product yield by causing the death of non-target beneficial and antagonistic bacteria were among the disadvantages of bacteriophage application (Ahmad and Morgan 1994). In a similar study, samples were collected from 6 different geographical sites in England. A total of 70 phages were isolated from soil (60), leaves (1), and bark (9) of cherry trees. The host specificity of the phage isolates was assessed against strains of pathovars of $P$. syringae. Hostrange experiments showed that it can infect/lyse not only different isolates of Pss and Psm but also other P. syringae pathovars, including $P$. s. pv. tomato DC3000, $P$. s. pv. lachrymans 789, and $P$. cichorii. However, the phages were unable to infect beneficial bacteria such as P. fluorescens. Two phage cocktails and 13 individual phage treatments were used against cultures of Pss, Psm1, and Psm2 to generate killing curves. All treatments were found effective for reducing the density of the bacterial host. However, there were substantial differences in the dynamics of bacterial killing by different groups of phages. Various concentrations of phages demonstrated different effects on bacterial populations. The highest titer of phage, the greatest their ability to inhibit the growth of the bacterial host, and in less time. A key consideration for phage use in biocontrol was storage and efficacy after storage. It has been reported that the largest the phage plaque, the best the phage survival at different temperatures (Rabiey et al. 2020).

In contrast, the combination of phages was less successful than specific individual phage treatments in this study. This result may be due to the fact that the ratio between phage and host bacterial density was not at the desired level or that phages applied in combination might compete among themselves. A related study emphasized the importance of multiple infections for natural phage populations. When a host was infected with multiple phages, it was shown that the lytic activity of prophages declined. The competition for the host among phages has been shown to be variable for each individual phage. Exploitation competition has been bound to occur, limiting resources in a bacterial cell. It has been suggested that interaction between two simultaneously executed lytic programs within the same cell may hinder efficient resource depletion. It has been reported that phages can be ranked according to their within-host competitive abilities. A phage that dominated intracellular processes was competitively superior (Refardt 2011).
In support of obtained results, a previous study found that one undesired feature of some phages was preventing the host's superinfection by the same or a closely related phage during phases of infection. Some phages in the same study were reported to prevent secondary infection of the host by another phage (Lu and Henning 1994).

\section{Conclusions}

Pss was found to be the most common disease agent of bacterial canker on cherry orchards in İzmir and Manisa provinces, Turkey. In vivo and in vitro results demonstrated that bacteriophage treatments had biocontrol effects against Pss via reducing the severity of the disease. In further studies, isolated bacteriophage particles will be observed using transmission electron microscopy (TEM) and investigate effective and protective formulations of bacteriophages.

\section{Abbreviations}

Pss: P. syringae pv. syringae; Psm: P. s. pv. morsprunorum; Pst: P. syringae pv. tomato; PTIF: Pathogenicity testing in immature fruits; pfu: Plaque-forming unit; cfu: Colony-forming unit

\section{Acknowledgements \\ I would like to thank Dr. Monika Kaluzna (Research Institute of Horticulture in Skierniewice, Skierniewice, POLAND) for providing reference strains that have been used in the study and AGROMILLORA Ltd. Sti. (Turkey) and the company's general manager Serhat Bozer for supplying micropropagated cherry plantlets.}

\section{Authors' contributions}

This article was produced from the corresponding author's thesis of the doctorate. MA contributed to the different stages of the process of the research such as research concept and design, collection, and/or assembly of the data; data analysis and interpretation; and writing the article (contribution rate 60\%). $\mathrm{HO}$ conceived the study and participated in its design and coordination (contribution rate 40\%). Both authors read and approved the final manuscript.

\section{Funding}

This work was supported by the Ege University Teaching Staff Training Program (OYP) coordination unit within the scope of OYP.

Availability of data and materials

Not applicable

Ethics approval and consent to participate

Not applicable

Consent for publication

Not applicable

\section{Competing interests}

The authors declare that they have no competing interests. All authors have reviewed the manuscript and approved its submission to the Egyptian Journal of Biological Pest Control.

\section{Author details}

'Department of Plant Protection, Faculty of Agriculture, University of Igdir, 76000 Merkez, Igdir, Turkey. ${ }^{2}$ Department of Plant Protection, Faculty of Agriculture, University of Ege, 35100 Izmir, Turkey. 
Received: 27 November 2020 Accepted: 12 February 2021

Published online: 18 February 2021

\section{References}

Ahmad M, Morgan V (1994) Characterization of a cowpea (Vigna unguiculata) rhizobiophage and its effect on cowpea nodulation and growth. Biol Fertil Soils 18:297-301. https://doi.org/10.1007/BF00570632

Balogh B, Canteros BI, Stall RE, Jones JB (2008) Control of citrus canker and citrus bacterial spot with bacteriophages. Plant Dis 92(7):1048-1052

Bereswill S, Bugert P, Völksch B, Ullrich M, Bender CL, Geider K (1994) Identification and relatedness of coronatine-producing Pseudomonas syringae pathovars by PCR analysis and sequence determination of the amplification products. Appl Environ Microbiol 60:2924-2930

Born Y, Fieseler L, Marazzi J, Lurz R, Duffy B, Loessner MJ (2011) Novel virulent and broad-host-range Erwinia amylovora bacteriophages reveal a high degree of mosaicism and a relationship to Enterobacteriaceae phages. Appl Environ Microbiol 77(17):5945-5954. https://doi.org/10.1128/AEM.03022-10

Boulé J, Sholberg PL, Lehman SM, O'gorman DT, Svircev AM (2011) Isolation and characterization of eight bacteriophages infecting Erwinia amylovora and their potential as biological control agents in British Columbia. Can J Plant Pathol 33(3):308-317. https://doi.org/10.1080/07060661.2011.588250

Bultreys A, Gheysen I, de Hoffmann E (2006) Yersiniabactin production by Pseudomonas syringae and Escherichia coli, and description of a second yersiniabactin locus evolutionary group. Appl Environ Microbiol 72:38143825. https://doi.org/10.1128/AEM.00119-06

Buttimer C, McAuliffe O, Ross RP, Hill C, O'Mahony J, Coffey A (2017) Bacteriophages and bacterial plant diseases. Front Microbiol 8:34. https://doi. org/10.3389/fmicb.2017.00034

Cazorla FM, Torés JA, Olalla L, Pérez-García A, Farré JM, de Vicente A (1998) Bacterial apical necrosis of mango in southern Spain: a disease caused by Pseudomonas syringae pv. syringae. Phytopathology 88:614-620. https://doi. org/10.1094/PHYTO.1998.88.7.614

Cross T, Schoff C, Chudoff D et al (2015) An optimized enrichment technique for the isolation of Arthrobacter bacteriophage species from soil sample isolates. Jis Exp. https://doi.org/10.3791/52781

Crosse J, Hingorani M (1958) A method for isolating Pseudomonas morsprunorum phages from the soil. Nature 181:60-61. https://doi.org/10.1038/1 $81060 \mathrm{a0}$

Erkan S, Saygllı H (1987) The preliminary studies on the isolation of the bacteriophages of some phytopathogenic bacteria. J Turki Phytopathol 16: $71-76$

Ertimurtas D (2012) Sert çekirdeklilerde bakteriyel kansere neden olan Pseudomonas syringae pathovarlarinin klasik ve moleküler yöntemlerle tanisi. Yüksek Lisans Tezi (MSc), Ege Üniversitesi Fen Bilimleri Enstitüsü https://tez. yok.gov.tr/UlusalTezMerkezi/tezSorguSonucYeni.jsp. Accessed 07 Jan 2021

Faostat (2016) Production of cherries: top 10 producers. http://www.fao.org/fa ostat/en/\#data/QC/visualize. Accessed 18 Jan 2018.

Frampton RA, Pitman AR, Fineran PC (2012) Advances in bacteriophage-mediated control of plant pathogens. Int J Microbiol 2012:326452. https://doi.org/10.11 $55 / 2012 / 326452$

Gašić K, Ivanović MM, Ignjatov M, Calić A, Obradović A (2011) Isolation and characterization of Xanthomonas euvesicatoria bacteriophages. J Plant Pathol 93(2):415-423

lezzoni A, Wünsch A, Höfer M et al (2017) Biodiversity, germplasm resources and breeding methods. In: Cherries: botany, production and uses. CABI International, pp 36-59. https://doi.org/10.1079/9781780648378.0036

Janse J (2010) Diagnostic methods for phytopathogenic bacteria of stone fruits and nuts in COST 873. EPPO Bulletin/Bulletin OEPP 40:68-85

Kałużna M, Sobiczewski P (2009) Virulence of Pseudomonas syringae pathovars and races originating from stone fruit trees. Phytopathologia 54:71-79

Kasman LM, Kasman A, Westwater C, Dolan J, Schmidt MG, Norris JS (2002) Overcoming the phage replication threshold: a mathematical model with implications for phage therapy. J Virol 76:5557-5564. https://doi.org/10.1128/ jvi.76.11.5557-5564.2002

Kennelly MM, Cazorla FM, de Vicente A, Ramos C, Sundin GW (2007) Pseudomonas syringae diseases of fruit trees: progress toward understanding and control. Plant Dis 91:4-17. https://doi.org/10.1094/PD-91-0004

Klement Z, Rudolph K, Sands D (1990) Methods in phytobacteriology. Akademiai Kiado, Budapest, XIV, p 568

Kutter E, Sulakvelidze A (2004) Bacteriophages: biology and applications. CRC Press, Boca Raton, Florida, pp 5-27
Liu L, Kloepper J, Tuzun S (1995) Induction of systemic resistance in cucumber against Fusarium wilt by plant growth-promoting rhizobacteria. Phytopathology 85:695-698

Lu MJ, Henning U (1994) Superinfection exclusion by t-even-type coliphages. Trends Microbiol 2(4):137-139

Otto M, Petersen Y, Roux J, Wright J, Coutinho TA (2017) Bacterial canker of cherry trees, Prunus avium, in South Africa. Eur J Plant Pathol 151:427-438. https://doi.org/10.1007/s10658-017-1384-5

Payne RJ, Jansen VA (2001) Understanding bacteriophage therapy as a densitydependent kinetic process. J Theor Biol 208(1):37-48

Pelzek AJ, Schuch R, Schmitz JE, Fischetti VA (2013) Isolation, culture, and characterization of bacteriophages. Current Protocols 7(1):4.4.1-4.4.33. https:// doi.org/10.1002/9780470089941.et0404s07

Rabiey M, Roy SR, Holtappels D, Franceschetti L, Quilty BJ, Creeth R et al (2020) Phage biocontrol to combat Pseudomonas syringae pathogens causing disease in cherry. Microb Biotechnol 13(5):1428-1445. https://doi.org/1 $0.1111 / 1751-7915.13585$

Reanney DC, Marsh SCN (1973) The ecology of viruses attacking Bacillus stearothermophilus in soil. Soil Biol Biochem 5(4):399-408

Refardt D (2011) Within-host competition determines reproductive success of temperate bacteriophages. ISME J 5(9):1451-1460. https://doi.org/10.1038/ ismej.2011.30

Schaad NW, Jones JB, Chun W (2001) Laboratory guide for the identification of plant pathogenic bacteria. vol ed. 3. American Phytopathological Society (APS Press), St Paul, USA, p 373

Sorensen KN, Kim KH, Takemoto JY (1998) PCR detection of cyclic lipodepsinonapeptide-producing Pseudomonas syringae pv. syringae and similarity of strains. Appl Environ Microbiol 64:226-230

Türkoglu K, Cınar Ö, Öktem Y (1977) Sivas ve Malatya illerinde kayısı ağaçlarında kurumaların sebebleri ve en uygun mücadele metodunun tesbiti üzerinde araştırmalar. TÜBITAK Yayınları, p 332

Vicente J, Roberts S (2003) Screening wild cherry micropropagated plantlets for resistance to bacterial canker. In: Pseudomonas syringae and related pathogens. Springer, pp 467-474

\section{Publisher's Note}

Springer Nature remains neutral with regard to jurisdictional claims in published maps and institutional affiliations.

\section{Submit your manuscript to a SpringerOpen ${ }^{\circ}$ journal and benefit from:}

- Convenient online submission

- Rigorous peer review

- Open access: articles freely available online

- High visibility within the field

- Retaining the copyright to your article

Submit your next manuscript at $>$ springeropen.com 